faculties which they may be charitably supposed to possess in common with other men. No progress in natural science is possible as long as men will take their rude guesses at truth for facts, and substitute the fancies of their imagination for the sober rules of reasoning.

It has been well observed by the greatest of living palæontologists, "that past experience of the chance aims of human fancy, unchecked and unguided by observed facts, shows how widely they have ever glanced away from the golden centre of truth!"

\title{
XLVI.-On the former Connexion of North Africa with South
} Europe. By Prof. Eidward Suess*.

A Letrer lately received from M. Anca, of Palermo, addressed to $M$. Senoner, induces me to return to a subject which $I$ have previously discussed, but the repeated consideration of which appears to me adapted to show the value which is possessed by the researches of M. Anca and some similar observations, even in connexion with the investigations now being carried out at Vienna.

On the former occasion, I mentioned, as having resulted from the investigations of our distinguished Professor Hörnes regarding the fossil Mollusca of the Vienna Basin, an unexpected identity of some species of our marine strata with shells now living on the coast of Senegambia.

I then named as examples Cypraa sanguinolenta, Buccinum lyratum, and Oliva flammulata, and inferred, in accordance with the descriptions we possess of the great Sahara, that a sea once extended from the Gulf of Gabes to the region south of the Idjil range in the province of Aderer uniting the Senegambian shores with those of the Mediterranean. I appealed to the detailed statements of Laurent, who was commissioned to execute Artesian borings on the north border of the desert. In his report, he represented the desert as once covered by a wide arm of the sea which flowed in from the Gulf of Gabes, and of which unmistakeable traces are to be seen in the repeated terraces along the south border of the Aoures Mountains, where the former positions of the sea-coasts are indicated also by one of the most abundant inhabitants of the Mediterranean coast, Cardium edule, the shells of which lie here strewn about in great quantities, and which is even said to be still living in some pools of the desert. I also added that, at present, considerable tracts of the

* From the Transactions of the Royal Imperial Geological Institution of Vienna, January 1863. Communicated by Mr. S. P. Woodward. 
desert still lie far below the level of the sea, and that the widespread saline incrustations have from the remotest times been regarded as proofs of a former overflow of the sea.

With the progress of Hörnes's investigations, indications of the accuracy of this conclusion have increased. Not only have we become acquainted with several species of bivalves whose present distribution extends as far as the Senegal, such as $\mathbf{L u}$ traria oblonga, Tellina crassa, T. lacunosa, Venus ovata, and three of our four species of Artemis, namely, A. exoleta, A. lincta, and $A$. Adansoni, but we now meet in our basin with some of the most prominent of Adanson's types, which at present are only to be found living on the coast of Senegambia, namely, Adanson's "Tugon" (Tugonia anatina) and "Vagal" (Tellina strigosa): the great Mactra Bucklandi, also, no longer living on European shores, is met with still at the Senegal. All accounts of the desert, however, agree so closely with the supposition of an overflowing, that, independently of these palæontological indications, other observers as well as Laurent were led to it solely by the form and constitution of the soil. Barth appears to have kept to the old Roman road between Tripoli and Mourzuk, almost always beyond the easterly margin of this ancient sea; and it would not be uninteresting to ascertain how far the outlines of this sea agree with Duveyrier's account of the boundaries of the land.

The present land-fauna of Morocco and Algeria, as far as Cyrenaica, agrees at the present time in its most essential points entirely with that of South Europe-on the one hand with that of the Pyrenean peninsula, and on the other with that of South Italy; whilst on the Senegal and Gambia, and the other successive regions beyond the desert, as far as the Nile, only the true African type appears. The elephant, rhinoceros, hippopotamus, giraffe, crocodile, and many other important members of the African fauna do not extend beyond the Sahara; and the contrast of this Morocco-Algerian land-fauna is very remarkable, as opposed to the true African fauna in most classes of animals, whilst the connecting links with Europe are not to be mistaken.

Moritz Wagner's ' Journey in the Kingdom of Algeria' contains numerous proofs of this, and they increase with every comparison. The extension of the Inuus ecaudatus to Gibraltar is well known. The Sorex etruscus, an otherwise exclusively Italian animal, is met with in Algiers. The fox, paler in Italy than in Germany, appears in Algeria as a still lighter variety. Of greater value for these investigations is the distribution of reptiles, as they are very little influenced by man; and it may be mentioned that the new 'Algerian Herpetology' of 
Strauch contains most of the known reptiles of Southern Europe, as Cistudo europaa, Lacerta viridis, Tropidonotus natrix, Rana esculenta, \&c., and that others, as the Chamaleo africanus, are known to occur in Spain and Sicily. Erichson, from the examination of Wagner's collection, observes of the Coleoptera- "A certain number of species belong to the fauna of Middle Europe; a greater portion is spread over all the coast-lands of the Mediterranean Sea; a few of these are, but the greater portion are not, Egyptian, the Egyptian fauna partaking more of the character of that of Central Africa. Algeria has most species in common with the adjacent Italian islands, Sicily and Sardinia, but fewer with the Italian mainland, as is the case with the Spanish peninsula and the proximate Morocco land; and it is often found that Spanish-Moroccan and Italian-Algerian species stand to each other in analogous relations."

It is the same with the land-Mollusca. According to Forbes, the agreement between the species of Morocco and Spain is so great that, even upon the heights, the Spanish mountain-snails reappear. Glandina algira occurs, in a slenderer form, from Isonzothale to Constantinople, whilst the broader variety unites Lower Italy, Sicily, and Algeria; other SouthEuropean species, which appear to have come from theEast, are, on the contrary, absent in Algeria, as Cyclostoma elegans, whilst Cyclostoma sulcatum is found upon the Italian islands and Malta, in the South of France, and South-east Spain, and also in North Africa. All the South-European freshwater bivalves are said to occur in Algeria. In the vegetable kingdom, to avoid giving superfluous examples, it may suffice to mention Chamarops humilis and its distribution on the coast of the Mediterranean. After this it will not be wondered at if, taking another line of argument, Andrew Wagner wrote, in the year 1846, " In a natural-history point of view, the Mediterranean separates North Africa much less from Europe than the Sahara separates it from the African continent. According to all evidence, the Sahara was once covered by the sea, and Barbary thus became an island in the Mediterranean."

The present land-fauna also leads us to recognize a close connexion between the Canary Islands, Morocco, Algiers, and Southwestern Europe, the extension of which to Cornwall was rendered probable by the late Edward Forbes. This fauna is called the Lusitanian land-fauna.

Let us now proceed to the investigations of M. Anca. In June 1860 , M. Anca succeeded in finding in the bone-caves of Sicily a number of determinable remains accompanied by land- or seashells, such as Helix aspersa and Cardium edule, which are living at this day : the richest list, that of the Grotto of S. Teodoro, is 
as follows, according to Lartet:- the spotted hyæna, a bear (Ursus arctos ?), wolf, fox, porcupine, rabbit, Elephas antiquus?, E. africanus?, hippopotamus (one or two species), Sus (probably Sus scrofa) resembling the North-African, ass?, ox (two forms), stag (one or two species), sheep or some similar animal, a large toad, and a bird. The recent letter of $M$. Anca confirms the occurrence, in this grotto, of Elephas africanus, while E. antiquus belongs to deposits of another date. We have therefore here, along with typical European forms, as, for example, stags and bears, which are quite foreign to Southern and Eastern Africa, and of which even Morocco and Algiers possess very few representatives (bears, perhaps only fossil, in caves), a small number of such animals as no longer pass beyond the region of the desert, but are Nilotic and Abyssinian, the African elephant, species of hippopotamus, and a hyæna, not the striped species which at present lives in North Africa and frontier India, but the spotted hyæna which inhabits South and West Africa. These Sicilian bone-caves prove, therefore, the existence of a close contact between South-European and genuine African types, which is nowhere seen in our day. This fact gains in importance if we bear in mind that similar points of contact could also be pointed out in Spain, at the time when the prevailing types of both the faunas were living. It must not be overlooked that, at an earlier period Cuvier sought the nearest representatives of our diluvial fauna in Southern Africa, even at the Cape; and that our rich antilopean fauna of Pikermi and Baltavar has a decided African character.

At the present time it is scarcely possible even to conjecture in what way and by what causes the disappearance from Europe of the present African group of forms, which long had their home in our part of the world, was brought about. M. Anca tells us that, even during the existence of the present fauna, a connexion has continued. As a first indication of a communication, we regard the submarine ridge stretching from Sicily to the opposite coast of Africa, and respecting which Admiral Smyth has informed us that it comprises the extensive plateaux of the "Adventure Bank" and the Skirki Rocks, which must be the sunken Ara of Virgil. If, however, as stated, we are still ignorant of the causes of these changes, we are nevertheless already able not only to distinguish in the present population of Europe a certain number of independent form-groups of faunas, out of which the present population of Europe has sprung; but we can even give the succession in which they have appeared. The first still capable of being recognized is that which we call the African: it has long since disappeared; its last traces in Europe are made known to us by M. Anca. The second is the northern, the 
remnants of which still continue to exist on our high mountains, like an elevated stratum overlying all the others which live beneath. These lowest are, on the one hand, the western fauna, which we designate the Lusitanian, the types of which are the forms common to the North of Africa and Europe; on the other, the eastern fauna, which we may perhaps venture to call the Asiatic, and which is broken up into several members, depending on the physical differences existing, for example, between the Caspian Steppes and Asia Minor.

It is not my intention here to point out what relations the superposition of the individual faunas of the European seas bear to this; but we may draw attention to the fact that the Mollusca which Vienna has in common with Senegambia (as Tugonia anatina) were without doubt formerly inhabitants of some parts of the present Mediterranean east of Sicily, probably became extinct during the diluvial epoch, and were subsequently unable to regain their former abode. M'Andrew, it is true, informs us that, favoured by the current, some tropical species, as, for instance, Cymba olla, make their way through the Straits of Gibraltar to the North-African coast; but they do not proceed very far, and the character of the Mediterranean fauna is totally distinct from the Senegambian. We are accustomed to consider climatic variations as the essential cause of all these displacements of land- and sea-faunas and floras; and some distinguished naturalists in Switzerland, impressed with the great effects which the sirocco produces on their glaciers, have thought that they could explain the greater extension of the icemasses in former times by its absence. In this way they have arrived at the same result as that obtained by the study of palæontology, geology, and geographical distribution-namely, that the Sahara Desert, the source of the sirocco, was once covered with water. Upon the heights of a continental Europe a more severe climate may certainly have been produced by such a cause; but for Europe, broken up into a sort of archipelago (such as we must imagine it to have been at the time when the Senegambian Mollusca of to-day were living near Vienna), no great lowering of the temperature of the sea could have resulted, and the whole archipelago had, without doubt, notwithstanding the absence of the sirocco, a moderate sea-climate.

Questions and doubts still arise on all sides, but we are at least able to form some idea of the path we have to pursue in studying the origin of the present creation from the preceding, and by which it will be possible to arrive at a more correct conception of the repeated changes of the organic world. 


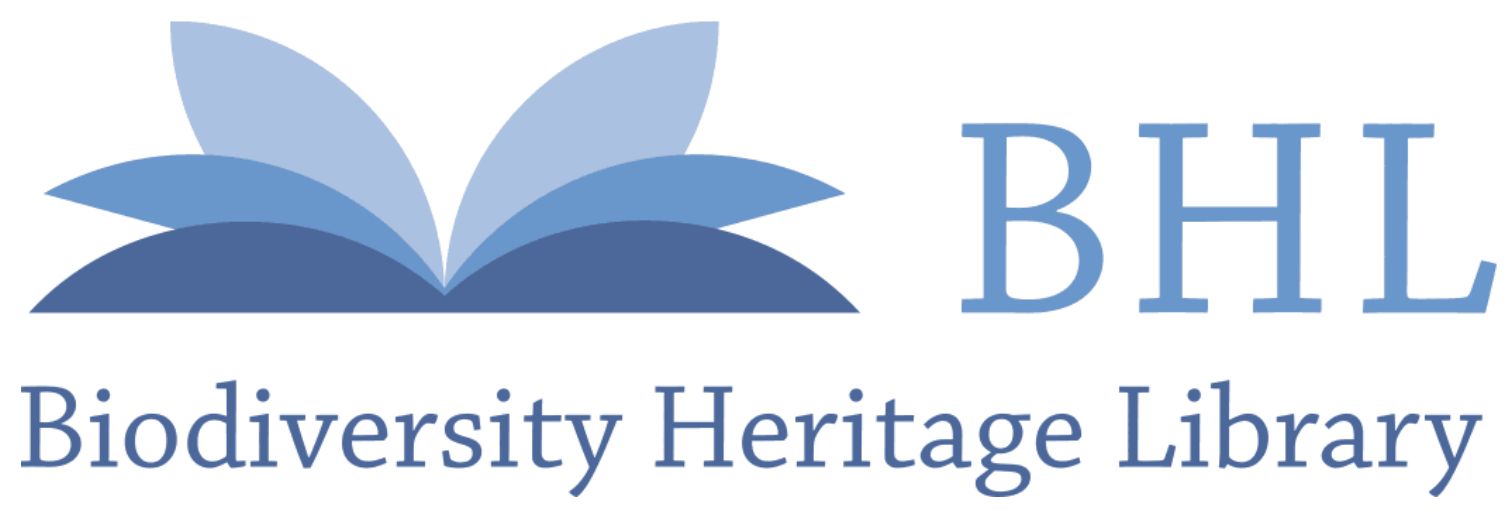

Suess, Edward. 1863. "XLVI.-On the former connexion of North Africa with South Europe." The Annals and magazine of natural history; zoology, botany, and geology 11, 429-433.

View This Item Online: https://www.biodiversitylibrary.org/item/72232

Permalink: https://www.biodiversitylibrary.org/partpdf/61209

\section{Holding Institution}

University of Toronto - Gerstein Science Information Centre

\section{Sponsored by}

University of Toronto

\section{Copyright \& Reuse}

Copyright Status: NOT_IN_COPYRIGHT

This document was created from content at the Biodiversity Heritage Library, the world's largest open access digital library for biodiversity literature and archives. Visit BHL at https://www.biodiversitylibrary.org. 